\title{
Maritime Security Trilateralism: India, Sri Lanka and Maldives
}

P K Ghosh*

\section{Abstract}

India perceives the entire Indian Ocean region (IOR) as its strategic backyard and regards itself as a "security provider" in the region. This view, of course, is not shared by many, mainly by the Chinese who often state "the Indian Ocean is not India's backyard." To reinforce its own perceptions and stem its eroding influence in the region - India has stepped up its efforts in enhancing its relations in general and on maritime security in particular with its island neighbours, an aspect that is being extended to the entire South Asian neighbourhood incrementally. The importance of the Mahanian concept of utilising Sea Power for the achievement of national objectives has led to the realisation amongst a normally 'sea blind' Indian bureaucracy to become more proactive. This article explores the maritime policy of India with regard to its neighbouring littoral states in the Indian Ocean.

Keywords: Maritime Security, Trilateralism, Indian Ocean Region, India, Maritime Domain Awareness, Defence Cooperation.

\section{Introduction}

India perceives the entire Indian Ocean region (IOR) as its strategic backyard and regards itself as a "security provider" in the region.

* Observer Research Foundation (ORF), Mumbai, India; pkghosh_in@yahoo.co.uk 
This view, of course, is not shared by many, mainly by the Chinese who often state "the Indian Ocean is not India's backyard." They underline the fact that they too have deep interests in the region and have been active since they sent their first anti-piracy patrol to the Gulf of Aden to fight against Somalian piracy in 2008 as part of the concept of MOOTW (Military Operations other than War).

To reinforce its own perceptions and stem its eroding influence in the region - India has stepped up its efforts in enhancing its relations in general and on maritime security in particular with its island neighbours, an aspect that is being extended to the entire South Asian neighbourhood incrementally. Indeed, it is a process that began some time ago and was essentially pursued by the respective National Security Advisors of the countries which led to the signing of the Trilateral Maritime Security Cooperation Agreement by India, Sri Lanka and the Maldives in July 2013. However, undoubtedly the entire effort received an impetus with the March 2015 visit of the Indian Prime Minister Narendra Modi to three island nations, Sri Lanka,Seychelles and Mauritius. A visit to Maldives during the same tour was deliberately avoided in response to the volatile internal politics of the country, which had convicted the India backed former President Mohamed Nasheed with a thirteen-year prison sentence.

Most analysts and media while dissecting the rationale of the PM's tour tended to project it as a part of a focused effort at veering the hostcountries away from the growing Chinese influence in the region, but in reality it only represented a part of the larger picture as it carried forward the agenda that had been set in motion earlier by the help of the previous national security advisors (NSA) meetings. With this in the background it would be difficult to evaluate if the visit succeeded in stemming India's eroding influence or did it successfully see a reduction in the evolving Chinese "hold" over the countries.

However, the visit did manage to signal India's readiness to assume greater responsibility and overt leadership of the region, in a departure from its earlier ambiguous posture when India was reluctant to assume strategic leadership of the region despite being exhorted by the US to do so. Earlier, India had refused to play the 
role of a regional "headmaster" and preferred to work from the sidelines without much fanfare.

India had long harboured great power aspirations as a balance of power but paradoxically had always refused to take additional responsibility and assume overt leadership in a deeply contested region. Thus, this new post signified a strategic transitioning of sorts. This process of change commenced with India initiating the Indian Ocean Naval Symposium(IONS) maritime initiative wherein it played the role of an "unobtrusive fulcrum". Hence, the overt manifestations were much more in evidence in the current case of "maritime security trilateral" highlighted during the Modi visit.

At the heart of this new posturing is the Indian desire to build amultilateral maritime arrangement with Sri Lanka, Seychelles, Mauritius and Maldives. "We call this Indian Ocean outreach as 'SAGAR' said Prime Minister Modi in Mauritius during his visit. At another occasion, the Foreign Minister added:"We seek a future for Indian Ocean that lives up to the name of SAGAR- Security and Growth for All in the Region."However, it is noteworthy that India, Sri Lanka and Maldives have not been comfortable with the concept of a security alliance either in substance or in terms and hence have avoided the same amongst themselves or with others. Interestingly none joined the earlier security constructs like the Southeast Asia Treaty Organisation (SEATO) or Central Treaty Organisation (CENTO). Hence, the coming together of these nations on a security related platform signifies the evolving geopolitics of the region and the national priorities of the countries involved.

The NSA level Meetings earlier hadn't involved all the islands together, and the main agenda was simply to create a closer functional operative only on maritime security within the given three islands (to be later expanded to other islands as well). Given that all the islands in the region lacked maritime capacity, India stepped in to promise in assisting in the capacity build-up. Thus, the focus essentially was to bring these countries to a common grid of a multilateral maritime security framework, reiterating India's new policy of 'neighbours first.' 


\section{Factors contributing to Maritime Security Trilateral}

There were many factors which contributed to the formation of the trilateral network. The primary one which provided the impetus was the maritime challenges faced by the countries were similar if not identical. Asymmetric threats such as maritime terrorism, arms and drug trade, piracy, human and weapons smuggling, were essentially transnational in characteristics requiring multinational response strategies - which made it incumbent on India with its large maritime capacity to provide the lead as well as help in building them maritime capacity of its friendly neighbours.

Apart from such threats, the necessity of maintaining an advanced level of Maritime Domain Awareness (MDA) as part of the overall response strategy was another aspect which led to the focus on the sharing of technical aspects of MDA. IOR being the hub of many natural calamities - the brunt of which had often been faced by the littorals, it was inevitable that disaster management and Humanitarian Assistance and Disaster Relief (HADR) become a factor that brought the countries together. With Indian forces providing yeoman services during the Tsunami of 2004 - it was natural for India to assume leadership in this regard.

Apart from the above, the dire need to ensure Sea Lanes of Communication (SLOC) security and unhindered passage of maritime trade was another aspect that helped in coming together of the countries since all the littorals were deeply dependent on maritime trade for their economic well-being. Similarly, the increasing role of China in fostering its bilateral relations with the island neighbours was one of the most important factors strategically to initiate this movement. The Indians perceive such moves by China in their strategic backyard as being inimical to their interests. The numerous construction projects of ports, infrastructure and base facilities in the IOR by China is a matter of great concern for India as it diminishes its strategic leverages. The construction of Hambantota port in Sri Lanka with Chinese money and material and anchoring of Ming class diesel submarine at a private dock in Colombo port, built, controlled and run by a Chinese company, the China Merchants Holdings (International) within the Sri Lankan administered harbour, is a case in point. It is 
probably for this reason that New Delhi is apprehensive about China's "Maritime Silk Route" concept.

\section{India's security relations with Sri Lanka}

The Indian Prime Minter's visit to Sri Lanka held deep significance as it was the first one in 28 years and it occurred at a time when China's growing presence in Sri Lanka had suffered a setback with the defeat of Mahinda Rajapaksa. Earlier, a considerable amount of heartburn had resulted from Rajapaksha's perceptible tilt towards China. A series of incidents had convinced the Indian Government that it needed serious discussion with the Sri Lankans on the issue as the repeated docking of Chinese submarines at the harbour had caused serious security concerns for India. Fortunately for India, a subsequent change in government brought respite and the new Sirisena government has made its desire publicly to correct the earlier tilt towards China and has already made some significant overtures towards India. The new President has visited India as his first trip abroad which resulted in a civil nuclear energy cooperation pact between India and Sri Lanka. In a move that risks adiplomatic row with its largest trading partner, Sri Lanka has suspended a $\$ 1.4$ billion Chinese luxury real estate project in Colombo. ${ }^{1}$

Having overcome the baggage of history, it needs to be mentionedthat the two armed forces of India and Sri Lanka support a close service to service relationship. Training exchanges at differing levels of seniority have been common and continue to be popularly subscribed. Military intelligence sharing had continued since earlier times when on several occasions such information helped the Sri Lankan Navy to intercept arms shipments to the LTTE successfully.

However, paradoxically despite the close Defence cooperation between the countries, one of the biggest unfinished agendas has been the absence of a formal Defence Cooperation Agreement (DCA) even though it has been in discussion since 2003. Domestic compulsions on either side have prevented the final signing of the DCA. The encouraging aspect, however, has been that the lack of a formal defence agreement has not been a real constraining factor in enhancing the level of defence cooperation between the two 
countries. For example, despite a political controversy that erupted in Tamil Nadu in 2013, India continues to train Sri Lankan personnel and officers. Additionally, New Delhi and Colombo had also commenced a formal Annual Defence Dialogue (ADD) in February 2012.

In the field of equipment transfers, even though India has steadfastly maintained its public posturing about not supplying offensive military hardware to Sri Lanka, it has quietly decided to extend a 100 million dollars credit line for purchase of non-lethal weapons. In fact, since 2000, India has supplied 24 L-70 anti-aircraft guns, 11 USFM radars, 10 Mine Protected Vehicles and 24 Battlefield Surveillance Radars to Sri Lanka.

\section{India's Security Relations with Maldives}

India and Maldives both have developed close strategic, military, economic and cultural relations over the many years. The closeness was particularly evident when India intervened militarily at the request of the President of Maldives and prevented a coup in November 1988. Operation Cactus as it was termed was a success and prevented the overthrow of President Gayoom by a Maldivian named Abdullah Luthufi and his group assisted by 80 heavily armed mercenaries of the People's Liberation Organisation of Tamil Eelam (PLOTE). On request from President Gayoom, the Indian government dispatched 1600 troops by air who finally overcame the mercenaries and prevented the coup. The event firmly established India's role as a security provider in the entire region as New Delhi's role was well appreciated by the international community.

The reiteration that India was emerging as a security provider came up again whenMaldives approached New Delhi in 2009, over fears that one of its island resorts could be taken over by terrorists given its lack of military and surveillance capabilities. In the meantime, due to an agreement signed in 2009, the following actions had already been initiated

a) India has permanently based two helicopters at Maldives for surveillance. One Advanced Light Helicopter (ALH) basedin Addu Island and the other more advanced helicopter to be based in Hannimadhoo Island. 
b) Maldives has coastal radars on only two of its 26 atolls. India helped in setting up radars stations in all 26 for seamless coverage

c) The coastal radar chain in Maldives will be networked with the Indian coastal radar system. India has already undertaken a project to install radars along its entire coastline. The radar chains are being interlinked and a central control room in India's Coastal Command.

In addition to the above defence arrangements, the Indian Coast Guard (ICG) has been tasked to utilise its Dornier aircraft for regular surveillance sorties over the island. The aim is to have active airsurveillance and patrolling against the emergent threat from Somali pirates, and these Dornier sorties have helped in easing the threat perception. Besides, India-Maldives-Sri Lanka also held a Joint Trilateral Coast Guard exercise called DOSTI XI off the coast of Male (Maldives) in April 2012 which looked at areas of common interest and enhanced interoperability between the forces.

\section{Earlier NSA Meetings and its Outcome}

The process of trilateralism had actually commenced with the intensive staff level talks that were followed by the NSA level talks which provided the impetus for the initiative and in the development of a trilateral security partnership and the Agreement. The first such meeting was held in Male in October 2011 which had preceded four separate meetings of senior officials between the three sides. This preparatory work by the working level was useful in framing the outcomes of the Second NSA-level Trilateral Meeting.

The second meeting of the NSA was hosted by Sri Lanka and held in Colombo in July 2013. The three participating countries agreed on a roadmap for cooperation in maritime security, comprising the following three categories of activities:

- Initiatives to enhance Maritime Domain Awareness (MDA) especially initiatives such as Long Range Identification and Tracking (LRIT) services and sharing of Automatic Identification System (AIS) data; 
- Training and capacity building initiatives in areas of MDA, Search and Rescue, and Oil Pollution Response; and

- Joint activities including trilateral exercises, maintaining lines of communication on illegal maritime activities, formulation of marine oil pollution response contingency plans and cooperation in legal and policy issues related to piracy.

India hosted the third NSA-level Trilateral Meeting on Maritime Security Cooperation between Maldives, Sri Lanka and India on 6 March 2014 in New Delhi. The same three primary interlocutors who had participated in the earlier meetings did so this time. Accordingly, theIndian team was led by Ambassador Shivshankar Menon, while the Maldivian side was headed by Col (Retd) Mohamed Nazim, Minister of Defence (MoD) and National Security and Mr Gotabaya Rajapaksa, Secretary, MoD and Urban Development of Sri Lanka headed his country's delegation. The important aspect was that the meeting was also attended by Mauritius and Seychelles which implied that they too would become part of the grouping.

This meeting discussed the progress of implementation of various activities that had been identified earlier. They also discussed new areas of cooperation including hydrography; training in Visit, Board, Search and Seizure Operations; training on board Indian Sail Training Ships; exchanges between think tanks; and joint participation in adventure activities. Given India's horrific experience with the Mumbai blasts there was a realization that terrorism was a transnational crime that demanded the active participation of all littorals whose maritime capacity needed to be built as there is a dire necessity to invest in MDA - specifically Long Range Identification and Tracking (LRIT) and the Automatic Identification System (AIS). Thus, it provided India with the unique opportunity to share its technological expertise with its allies for maritime capacity enhancement.

The other topics of discussion included Search and Rescue (SAR). It was agreed that India would also provide expertise and technical assistance for setting up/ enhancing Maritime Rescue Coordination Centres (MRCCs) in Sri Lanka² and Maldives for effective 
coordination in relaying and receiving distress alerts and safety messages. Given the current focus on preventing/controlling maritime pollution that not only to destroys marine environment but has considerable security considerations- this was another topic for discussion. With Indian Coast Guard (INCG) and US Coast Guard being the few maritime agencies that were capable of tackling oil pollution it was decided that there be considerable scope for promoting marine oil pollution response cooperation with the appropriate agencies of these island nations.

One of the most important issues that were discussed was the rise of asymmetric challenges especially terrorism and piracy in the region. Both these aspects scored high in the threat perception of the participating littorals. As a consequence, there were extensive discussions on the need to expand 'DOSTI' (friendship) exercises 3 by holding table top exercises and further enhancing sharing of the information on illegal maritime activities through existing points of contact. Additionally, there was also a consensus on forming a trilateral sub-group which would focus exclusively on the complexities of policy and legal issues related to piracy. With India having been unable to finally pass a national legislation (Piracy Bill 2012) to overcome a serious hurdle in the prosecution of apprehended pirates - this was an issue that was significant in dealing with anti- piracy operations.

These meetings chalked out the entire roadmap for future security cooperation outlining the following:

a. The facility of the Indian Long Range Identification and Tracking (LRIT) Data Centre to be used by Sri Lanka and Maldives to monitor and track their merchant vessels flying their flags. In turn, Sri Lanka and Maldives are to provide required details of their merchant ships as per International Maritime Organisation (IMO) regulations.

b. The Merchant Ship Information System (MSIS) be utilised for exchange of unclassified information on shipping;

c. Sharing Automatic Identification System (AIS) data in a trilateral format over the MSIS platform;

d. Undertaking MDA training in India; 
e. Strengthening maritime linkages in the field of SAR through operations, providing expertise and technical assistance to India in setting up Maritime Rescue Coordination Centres (MRCCs) in Sri Lanka and Maldives, coordination in relaying and receiving distress alerts and safety messages, and, conduct of SAR training in India;

f. Strengthening mechanisms for Exclusive Economic Zone (EEZ) surveillance and providing additional support and assets on a case by case basis;

g. Maintaining lines of communication on illegal maritime activities between identified Points of Contact and exchanging messages on a regular basis;

h. Strengthening marine pollution response cooperation through conduct of IMO Level I and Level II courses in India, formulating contingency plans for pollution response, capacity building, and participating in India's National Pollution Response Exercise (NATPOLREX), as observers;

i. Strengthening the biennial trilateral exercise 'DOSTI' by conducting table top exercises and seminars on maritime issues in every alternate year;

j. Passing Tsunami warnings simultaneously to agreed Points of Contact and also to the designated National Tsunami Warning Centres;

k. Setting up a trilateral sub-group focused on legal and policy issues related to piracy.

\section{Beyond Trilateralism}

The concept of comprehensive security in modern usage has an accent on cooperative approaches but using and sharing of latest technology in capacity building is a relatively new idea within the IOR especially for India which was hindered by its previous isolationisticmindset that was prominent during the Cold War era. Undoubtedly, the success of getting its island neighbours within maritime security grid will be expanded furtherin due course of time - as is evident from the willingness of the other islands to follow suit. Given that these islands face similar maritime 
challenges such a symbiotic arrangement seems mutually beneficial to all. Thus very soon Mauritius and Seychelles, which share strong bilateral relations with India, are most likely to join in this arrangement.

Strategically, the Indians have been wary of the growing influence of the external powers in the region - mainly with respect to China. Hence at the subterranean level, this dynamic arrangement will partly offset the growing influence of China and Pakistan in the regional dynamics. Additionally, the current arrangement will provide India with the option to develop forward bases in the entire region if the need arises. With the available technology and the willingness of the participating countries these bases could well be notional or real. Thus, in a master stroke, it will enable India to retain its public posturing against military forward basing in the region and thus maintain moral high ground - while possessing the ability to assess the farthest regions with technological means without the overwhelming physical presence of its military troops in that area.

The task is likely to be made easier since India is normally perceived as a benign power in the Indian Ocean, in sharp contrast to the perception of a hegemonic China which supports an intrusive way of providing aid and capacity building assistance. Hence, it might be easier for the littorals to readily join the bandwagon willingly rather than be swayed by Chinese inducements. Admittedly, there exists another major maritime security initiative known as the Indian Ocean Naval Symposium (IONS), initiated by India in 2008 that aims at bringing the IOR littoral navies together for active discussions on matters of common maritime interest. However, this regional forum of navies is decidedly naval in its outlook and can supplement a more holistic overview of security cooperation in the region. With a perceptible "cooling" of IONS ability to gather other littorals in enhancing the maritime dialogue- such trilateral or multilateral agreements are more potent and efficient in achieving their objective. 


\section{Conclusion}

The importance of the Mahanian concept of utilising Sea Power for the achievement of national objectives has led to the realisation amongst a normally 'sea blind' Indian bureaucracy to become moreproactive. It is now being understood that naval diplomacy and projection of maritime power can help India in achieving its objectives of being a net security provider in a region perceived to be its strategic backyard. With this background, the rise of maritime threats from the seas and the lack of maritime capacity amongst many friendly littorals has resulted in a symbiotic relationship of sorts and resulted in India drawing close two of its neighbouring islands. The first step in this regard has been the signing of the security related Trilateral Maritime Security Cooperation Agreement by India, Sri Lanka and the Maldives with such an arrangement to be expanded to all its friendly island neighbours.

Simultaneously, these efforts have helped India to stem its eroding influence in the region while denuding the increasing influence of foreign powers, mainly China in the region. Strategically India's initiative 'neighbours first' policy that has regionally manifested into getting the friendly island nations on a common maritime security grid has strenuously reiterated India's position as a net security provider. This has also ensured that India retains strategic leverages against adversarial powers that have been active in fostering their influence in the region. However, it remains to be seen how far India can nourish this symbiotic relation with its neighbours and continue offsetting the Chinese influence in the years to come.

\section{References}

Ghosh, P. K. (2012). Indian Ocean Naval Symposium: Uniting the Maritime Indian Ocean Region. Strategic Analysis, 36(3), 352-357. doi:10.1080/09700161.2012.670482

Ghosh, P. K. (2014, May 08). IONS and the Indian Ocean: Reviving a Listless Initiative. RSIS Commentary. No.083/2014.

Gokhale, N. (2012, December 18). Army Chief visits Colombo to further Indo-Sri Lankan defence ties. Retrieved July 11, 2016, from 
http:/ / www.ndtv.com/india-news/army-chief-visits-colombo-tofurther-indo-sri-lankan-defence-ties-507912

Gosh, P. K. (2011, April 05). Indian Ocean dynamics: An Indian perspective | East Asia Forum. Retrieved July 10, 2016, from http:/ / www.eastasiaforum.org/2011/04/05/indian-ocean-dynamicsan-indian-perspective/

Joint Statement by India and Maldives on the Visit of the President of Maldives to India. (2012, May 14). Retrieved June 21, 2016, from http://mea.gov.in/bilateral-documents.htm?dtl/19869/Joint

Statement by India and Maldives on the Visit of the President of Maldives to India

NSA level meeting on trilateral Maritime Security Cooperation between India, Sri Lanka and Maldives. (2014, March 06). Retrieved June 13, 2016, from http://mea.gov.in/in-focus-article.htm?23037/NSA level meeting on trilateral Maritime Security Cooperation between India Sri Lanka and Maldives

Outcome Document of the Second NSA-Level Meeting on Trilateral Cooperation on Maritime Security between India, the Maldives and Sri Lanka. (2013, July 09). Retrieved June 13, 2016, from http:/ / www.mea.gov.in/bilateral-documents.htm?dtl/

21922/Outcome Document of the Second NSA Level Meeting on Trilateral Cooperation on Maritime Security between India the Maldives and Sri Lanka

Pubby, M. (2009, August 13). India Bringing Maldives into its Security net. Retrieved June 07, 2016, from http://www.indianexpress.com/ news/India-bringing-Maldives-into-its-security-net/501583

Singh, A. (2015). China's "Maritime Bases" in the IOR: A Chronicle of Dominance Foretold. Strategic Analysis, 39(3), 293-297.

Sri Lanka signs maritime cooperation Agreement with India and Maldives. (n.d.). Retrieved June 15, 2016, from http://www.srilankaembassy.be/old/HomePagePhoto/2013/

Doc36.pdf

Swaraj, S. (2015, March 20). Address presented at India and Indian Ocean: Renewing the Maritime Trade and Civilisational linkages, Bhubaneswar. Retrieved from http://pib.nic.in/ newsite/ PrintRelease.aspx?relid=117542 


\section{Endnotes}

1 The Sri Lankan government's decision to review, and in effect suspend, the \$US1.4 billion, Chinese-backed Colombo Port City (CPC) project strained relations between Beijing and Colombo considerably. The plan was to construct a modern 500 -acre ( 230 hectare) city, with hotels, apartments and office buildings, on earth fill near the seafront of Colombo harbor. About 200 acres were to be held by China Communications Construction Company (CCCC), the main contractor, on a 99-year lease. The deal was sealed during Rajpaksha's time. Also see Fernando, M. (2015, March 16). World Socialist Web Site. Retrieved July 09, 2016, from https://www.wsws.org/en/ articles/2015/03/16/chin-m16.html

2 India currently has three MRCCs (at Mumbai, Chennai and at Port Blair) in its Search and Rescue Region (SRR) as well as numerous Maritime Rescue Sub Centres (MRSC's) There exists an MRCC in Colombo

3 Exercise "Dosti" (Friendship) was started as a bi-annual exercise between the Coast Guards of India and Maldives in 1991 with the objective of strengthening co-operation. In its 20th year it included (2012) the Sri Lankan Coast Guard. 